BIOMEDICINE

\title{
Ischemic stroke in Ukrainian population: possible involvement of the $F 2$ G20210A, F5 G1691A and MTHFR C677T gene variants
}

\author{
P. F. Tatarskyy ${ }^{1,3}$, A. M. Kucherenko ${ }^{1,3}$, S. A. Kravchenko, \\ D. V. Shulzenko' , S. M. Kuznetsova ${ }^{2}$, L. A. Livshits ${ }^{1}$
}

\begin{abstract}
${ }^{1}$ Institute of Molecular Biology and Genetics National Academy of Sciences of Ukraine 150, Akademika Zabolotnogo Str., Kyiv, Ukraine, 03680

${ }^{2}$ Gerontology Institute of the Academy of Medical Sciences of Ukraine 67, Vyshgorodska Str., Kyiv, Ukraine, 04114
\end{abstract}

${ }^{3}$ National Taras Shevchenko University of Kyiv 64, Volodymyrska Str., Kyiv, Ukraine, 01033

tatarskyy@yahoo.com

\begin{abstract}
Aim. To evaluate a possible involvement of the F2, F5, MTHFR gene variants into ischemic stroke pathogenesis in population of Ukraine. Methods. Polymorphic variants were analyzed in unrelated 183 stroke patients, 100 individuals from the general population of Ukraine and 88 healthy individuals elder than 65 years using PCR followed by RFLP analysis. Results. Unfavourable polymorphic variants F2 20210A, F5 $1691 \mathrm{~A}$ and MTHFR $677 T$ were observed more frequently in patients with ischemic stroke comparing to control groups. Conclusions. F5 $1691 \mathrm{~A}$ and MTHFR 677 polymorphic variants are associated with the occurrence of ischemic stroke in women. F2 20210A is associated with the occurrence of ischemic stroke in men. Cumulative risk factor for stroke development is revealed in a combination of unfavorable polymorphic variants 20210A, $1691 \mathrm{~A}$ and $677 T$ of F2, F5 and MTHFR genes.
\end{abstract}

Keywords: Factor V Leiden (F5 G1691A) gene, prothrombin (F2 G20210A) gene, methylenetetrahydrofolate reductase (MTHFR C677T) gene, ischemic stroke, combined genotype.

Introduction. Nowadays, stroke is one of the main causes of invalidization and mortality in the developed countries, being a crucial medical and social problem [1-8].

Stroke is defined as rapidly developing clinical signs of focal (or global) disturbance of cerebral function with symptoms, lasting $24 \mathrm{~h}$ or longer or leading to death, with no apparent cause other than of vascular origin [3]. Stroke is considered to be a complex polygenic disorder arising from a wide number of gene-

(C) Institute of Molecular Biology and Genetics NAS of Ukraine, 2010 gene and gene-environment interactions. Since the advent of molecular genetics in medicine it has been a focus of interest to clarify a role of mutations in various candidate genes and their impact on stroke development. A series of studies have been carried out to explain possible mechanisms of this ischemic event. The results of the study are not entirely consistent, but the majority of the data support the concept that thrombosis is important for ischemic stroke development [1-6].

The factor V (F5 G1691A) Leiden and G20210A variant of the prothrombin $(F 2)$ gene are clotting factor mutations that are associated with an increased 
tendency toward venous thrombosis $[1,4]$. The evidence of a role for these gene variants in the risk of ischemic stroke is controversial $[1,4,6]$.

The $\mathrm{G}$ to A transition at nucleotide position 20210 in the 3'-untranslated region of $F 2$ gene plays a regulatory role in the gene expression $[1,5,6,9]$. Prothrombin has procoagulant, anticoagulant and antifibrinolytic activities, and thus a disorder involving prothrombin results in hemostasis multiple imbalances [1, 5]. The $F 2$ G20210A gene mutation is associated with an elevated risk of deep vein thrombosis and consequently ischemic stroke $[1,6]$.

The point mutation of factor $\mathrm{V}(F 5 \mathrm{G} 1691 \mathrm{~A})$ leads to the structural change in the factor $\mathrm{V}$ molecule and makes it less susceptible to inactivation by activated protein C (APC) [7], resulting in a hypercoagulable state when more factor $\mathrm{Va}$ is available within the prothrombinase complex, thereby increasing the generation of thrombin leading to thrombosis and, therefore, ischemic stroke [1, 4, 6-8].

Hyperhomocysteinemia has been documented as an independent risk factor for stroke $[1,4]$. The most common form of genetic hyperhomocysteinemia results from production of a thermolabile variant of methylenetetrahydrofolate reductase with reduced enzymatic activity caused by C677T substitution in the MTHFR gene [1, 4]. Moderate elevation of homocysteine in the plasma is an established risk factor in the development of ischemic stroke and venous thrombosis due to its toxic influence on the endothelium. Concerning the connection of C677T MTHFR and a risk of stroke, the results are conflicting as well [1,4].

The aim of this study was to evaluate a possible involvement of the F2 G20210A, F5 G1691A, MTHFR C677T gene variants into stroke pathogenesis.

Materials and methods. Study subjects. Unrelated individuals who were randomly selected between 2008 and 2009 from different regions of Ukraine were included in this study. An informed consent was obtained from each participant prior to blood collection and DNA extraction.

This study was approved by the Ethical Committee of the Institute of Molecular Biology and Genetics of the National Academy of Sciences of Ukraine and by state institution «Institute of Gerontology of the Academy of Medical Sciences of Ukraine».
A case group included 183 patients (men - 95, women-88), who have survived after ischemic stroke and were referred for rehabilitation. The patients were documented according to a standardized protocol comprising the following information: vascular risk factors including hypertension, diabetes, cigarette smoking, body mass index, medical history including general medical diseases (e. g. previous cardiac, neurological, oncological diseases) and previous medication with particular reference to vascular diseases (TIA/stroke, venous thrombosis); laboratory and instrumental investigations including carotid and vertebral ultrasound, electroencephalography, echocardiography, MRI or CT; stroke cause and stroke severity as measured by validated scales. A control group I consisted of 100 individuals from the general population of Ukraine (men - 50, women - 50). A control group II included 88 healthy individuals elder then 65 years (men -35 , women - 53) without any history of ischemic stroke. No significant difference between the age of men and women within each group was observed.

Genotyping. DNA was extracted from the peripheral blood leukocytes by standard phenol-chloroform extraction method [10]. The $F 2$ gene G20210A and F5 gene G1691A allelic variants were identified by multiplex polymerase chain reaction (PCR) with the use of specific oligonucleotide primers followed by $\mathrm{Mnl}$ I restriction enzyme digestion, as described by Koksal et al., 2006 [11].

The MTHFR gene C677T allele was detected by PCR with the use of specific oligonucleotide primers followed by Hinfl restriction enzyme digestion, as described by Michael et al., 2008 [12].

Electrophoresis of the PCR products was performed in a $1.8 \%$ agarose gel. PCR products 169,221 and $294 \mathrm{bp}$ long correspondently were digested and run on $7 \%$ PAGE, the gels were stained with EtBr followed by visualization under UV.

Statistical analysis. The statistical analyses were performed using MDR, Genepop and Arlequin softwares [13-15]. Differences were considered significant at $\mathrm{P}<0.05$ value of Fisher exact test.

Results and discussion. Because we included individuals who have survived after ischemic stroke only, one could argue that this could have led to prejudiced results. Case fatality in stroke largely depends 
Table 1

Genotype and allele distribution among the study groups

\begin{tabular}{|c|c|c|c|c|c|c|c|c|c|}
\hline $\begin{array}{c}\text { Group } \\
\text { Loci }\end{array}$ & $\begin{array}{l}\text { Control group } \\
\text { I } n=100\end{array}$ & $\begin{array}{c}\text { Men } \\
n=50\end{array}$ & $\begin{array}{c}\text { Women } \\
n=50\end{array}$ & $\begin{array}{l}\text { Control group } \\
\text { II } n=88\end{array}$ & $\begin{array}{l}\text { Men } \\
n=35\end{array}$ & $\begin{array}{c}\text { Women } \\
n=53\end{array}$ & $\begin{array}{c}\text { Case group } \\
n=183\end{array}$ & $\begin{array}{c}\text { Men } \\
n=95\end{array}$ & $\begin{array}{c}\text { Women } \\
n=88\end{array}$ \\
\hline
\end{tabular}

F5 G1691A

Genotype, $n(\%)$

\begin{tabular}{|c|c|c|c|c|c|c|c|c|c|}
\hline GG & $98(98)$ & $50(100)$ & $48(96)$ & 85 (96.6) & $35(100)$ & $50(94.3)$ & 177 (96.7) & 94 (98.9) & $83(94.3)$ \\
\hline GA & $2(2)$ & $0(0)$ & $2(4)$ & $2(2.3)$ & $0(0)$ & $2(3.8)$ & $6(3.3)$ & $1(1.1)$ & $5(5.7)$ \\
\hline $\mathrm{AA}$ & $0(0)$ & $0(0)$ & $0(0)$ & $1(1.1)$ & $0(0)$ & $1(1.9)$ & $0(0)$ & $0(0)$ & $0(0)$ \\
\hline
\end{tabular}

Allele, $n(\%)$

\begin{tabular}{|c|c|c|c|c|c|c|c|c|c|}
\hline $\mathrm{G}$ & $198(99)$ & $100(100)$ & $98(98)$ & $172(97.7)$ & $70(100)$ & $102(96.2)$ & $360(98.4)$ & $189(99.5)$ & $171(97.2)$ \\
\hline A & $2(1)$ & $0(0)$ & $2(2)$ & $4(2.3)$ & $0(0)$ & $4(3.8)$ & $6(1.6)$ & $1(0.5)$ & $5(2.8)$ \\
\hline
\end{tabular}

Genotype, $n(\%)$

\begin{tabular}{|c|c|c|c|c|c|c|c|c|c|}
\hline GG & 97 (97) & $48(96)$ & $49(98)$ & $88(100)$ & $35(100)$ & $53(100)$ & $175(95.6)$ & $88(92.6)$ & 87 (98.9) \\
\hline GA & $3(3)$ & $2(4)$ & $1(2)$ & $0(0)$ & $0(0)$ & $0(0)$ & $8(4.4)^{* *}$ & $7(7.4)$ & $1(1.1)$ \\
\hline AA & $0(0)$ & $0(0)$ & $0(0)$ & $0(0)$ & $0(0)$ & $0(0)$ & $0(0)$ & $0(0)$ & $0(0)$ \\
\hline
\end{tabular}

Allele, $n(\%)$

\begin{tabular}{|c|c|c|c|c|c|c|c|c|c|}
\hline$G$ & $197(98.5)$ & $98(98)$ & 99 (99) & $176(100.0)$ & $70(100)$ & $106(100)$ & $358(97.8)$ & $183(96.3)$ & $175(99.4)$ \\
\hline 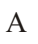 & $3(1.5)$ & $2(2)$ & $1(1)$ & $0(0.0)$ & $0(0)$ & $0(0)$ & $8(2.2)$ & $7(3.7)$ & $1(0.6)$ \\
\hline
\end{tabular}

MTHFR C677T

Genotype, $n(\%)$

\begin{tabular}{|c|c|c|c|c|c|c|c|c|c|}
\hline $\mathrm{CC}$ & $50(50)$ & $23(46)$ & $27(54)$ & $44(50)$ & $13(37.1)$ & $31(58.5)$ & 73 (39.9) & $33(34.7)$ & $40(45.5)$ \\
\hline $\mathrm{CT}$ & $45(45)$ & $25(50)$ & $20(40)$ & $37(42)$ & $20(57.2)$ & $17(32.1)$ & $87(47.5)$ & $49(51.6)$ & $38(43.1)$ \\
\hline $\mathrm{TT}$ & $5(5)$ & $2(4)$ & $3(6)$ & $7(8)$ & $2(5.7)$ & $5(9.4)$ & $23(12.6)^{*}$ & $13(13.7)$ & $10(11.4)$ \\
\hline$+\mathrm{TT}$ & $50(50)$ & $27(54)$ & $23(46)$ & $44(50)$ & $22(62.9)$ & $22(41.5)$ & $110(60.1)$ & $62(65.3)$ & $48(54.5) * *$ \\
\hline
\end{tabular}

Allele, $n(\%)$

\begin{tabular}{|c|c|c|c|c|c|c|c|c|c|}
\hline $\mathrm{C}$ & $145(72.5)$ & $71(71)$ & $74(74)$ & $125(71.0)$ & $46(65.7)$ & $79(74.5)$ & $233(63.7)$ & $115(60.5)$ & $118(67)$ \\
\hline & $55(27.5)$ & $29(29)$ & $26(26)$ & $51(29.0)$ & $24(34.3)$ & $27(25.5)$ & $133(36.3)$ & $75(39.5)$ & $58(33)$ \\
\hline
\end{tabular}

$n$-group size; F2: A - 20210A; G - 20210G, F5: A - 1691A; G - 1691G, MTHFR: T - 677T, C - 677C, **Significant at P < 0.05 between case and control group II, * Significant at $\mathrm{P}<0.05$ between case and control group I.

on age, $88 \%$ of all deaths from stroke occurring in people older than 65 years [4].

The average age between the groups was significantly different. In the control group II the individuals average age $(73.9 \pm 6.4)$ was higher than in the case group $(64.6 \pm 9.1)$, on the other hand, the average age of individuals in the control group I (30.2 \pm 7.6$)$ was lower than in the other groups.
To clarify a possible involvement of the $F 2$ G20210A, F5 G1691A, MTHFR C677T in stroke the analysis of above mentioned SNPs was performed. Genotypes and allele frequencies of the three polymorphisms are presented in Table 1.

After the molecular-genetical analysis we have established that the $F 220210$ A carriers frequency in the case group was $4.4 \%$, and in the control group II such 
carriers were not found. Significant difference was found between the frequency of men and women carriers of the $F 2$ 20210A from the case group, men had higher frequency $(7.4 \%)$ comparing to women $(1.1 \%)$. Similar findings regarding gender specific role of the $F 2$ 20210A, as significant risk factor of stroke in men but not in women, were reported previously [6]. We also found the evidence that the FV Leiden mutation is observed more frequently in women. A trend toward difference in the distribution of the F5 1691A was found between women $(5.7 \%)$ and men $(1.1 \%)$ from the case group.

We assume that these data, showing the genderspecific prevalence of the F2 20210A and F5 1691A mutations in the case group, suggest that the risk of stroke development for men and women, carrying the F2 20210A and F5 1691A mutations, is unequal. There are extensive epidemiological data showing that premenopausal females have reduced risk for cardiovascular disease than men of the same age, but the menopause initiates a phase of increased risk for cardiovascular disease (CVD) [16-19].

It was shown that endogenous estrogens increase the resistance to activated protein $\mathrm{C}$ regardless of the presence of the FVL mutation [6]. At the same time, several beneficial vascular effects of estrogen have been suggested, including modification of the composition of circulating lipoproteins, changes in blood coagulation, inhibition of intravascular accumulation of collagen, antiproliferative effects on vascular smooth muscle (VSM) cells, and direct vasodilation of blood vessels [20], and there are few reports on cardiac genes regulated by estrogen [21].

With age the estrogen concentration in plasma decreases, this may explain the enhanced vascular contraction in aging females. Postmenopausal hypoestrogenism has been suggested to increase arterial vascular tone through a decrease in vasodilator neuropeptides and an increase in vasoconstrictor peptides in the arterial wall nerve terminals of the autonomous nervous system [22].

Progesterone is expressed in both endothelial and vascular smooth muscle cells, stimulates endothelial nitric oxide synthase activity, NO production, and NOmediated relaxation, the effects of progesterone on vascular relaxation may be tissue specific [19]. The FVL mutation has been shown to further increase the risk of venous thrombosis in oral contraceptive and hormone replacement therapy users $[16,19]$.

Nevertheless, some evolutionary benefits for females carrying the FVL mutation, which are crucial for successful pregnancy outcome, were described by Gopel et al. [23], Majerus et al. [24], and Lindqvist et al. [25]. Women, who carry the FVL mutation lose less blood in menstruation, have higher haemoglobin levels, and possibly have a lower incidence of lifethreatening post-partum haemorrhage [25]. The positive effect on implantation was described [24] and verified in studies, where an improved implantation rate in the ICSI and IVF pregnancies was reported if either the mother or the child carried the FVL mutation [23]. Those benefits for pre-menopausal women become a disadvantage with age in post-menopause women with the loss of cardio protective function of estrogens.

Androgens have been shown to be important for survival, number of studies have linked androgen deficiency to increased mortality in men $[26,27]$. Testosterone is an anabolic hormone with a wide range of beneficial effects on men's health. Androgen receptors have been identified in the blood vessels of experimental animals and of humans [26]. In number of studies it was $[26,27]$ noted that testosterone $(\mathrm{T})$ deficiency might contribute to increased risk of CVD. It was found that men older than 25 years old presenting with hypertension had lower total $\mathrm{T}$ values [26]. The androgen deficiency was shown to be associated with increased levels of total cholesterol, low-density lipoprotein, increased production of proinflammatory factors, and increased thickness of the arterial wall and contributes to endothelial dysfunction [26, 27]. It was reported that endogenous $\mathrm{T}$ levels decline with age.

Thus, we suppose that endothelium dysfunction is increased in aging men due to testosterone level decline, so that it can be considered as an independent thrombosis risk factor. The observed higher frequency of the $F 220210$ A variant in men comparing to women with stroke confirms that the $F 220210 \mathrm{~A}$ variant might be an additional genetic risk factor of the stroke development in men.

Furthermore, we have established that, the MTHFR $677 \mathrm{~T}$ homozygous carrier's frequency in the case group in our study (12.6\%) was significantly higher than in the control group I ( $5 \%$ ). Genotype frequency 
Table 2

Combined genotypes frequencies of the F5 G1691A, F2 G20210A and MTHFR C677T genes variants

\begin{tabular}{|c|c|c|c|c|c|c|c|}
\hline \multirow{2}{*}{ Gender } & \multicolumn{3}{|c|}{ Genotype } & \multicolumn{2}{|c|}{ Case group } & \multicolumn{2}{|c|}{$\begin{array}{l}\text { Control group } \\
\text { II }\end{array}$} \\
\hline & $F 2$ & F5 & MTHFR & $n$ & $\%$ & $n$ & $\%$ \\
\hline Men & \multirow{2}{*}{ GG } & \multirow{2}{*}{ GG } & \multirow{2}{*}{$\mathrm{CC}$} & 32 & 33.7 & 13 & 37.3 \\
\hline Women & & & & 38 & 43.2 & 31 & 58.5 \\
\hline $\operatorname{Men}^{\dagger}$ & \multirow{2}{*}{ GA } & \multirow{2}{*}{ GG } & \multirow{2}{*}{$\mathrm{CC}$} & 1 & 1.05 & 0 & 0 \\
\hline Women $^{\dagger}$ & & & & 0 & 0 & 0 & 0 \\
\hline $\operatorname{Men}^{\dagger}$ & \multirow{2}{*}{ GG } & \multirow{2}{*}{ GA } & \multirow{2}{*}{$\mathrm{CC}$} & 0 & 0 & 0 & 0 \\
\hline Women $^{\dagger}$ & & & & 2 & 2.3 & 0 & 0 \\
\hline Men & \multirow[b]{2}{*}{ GG } & \multirow[b]{2}{*}{ GG } & \multirow[b]{2}{*}{$\mathrm{CT}$} & 44 & 46.3 & 20 & 57.2 \\
\hline Women $^{\dagger}$ & & & & 35 & 39.8 & 14 & 26.4 \\
\hline $\operatorname{Men}^{\dagger}$ & \multirow{2}{*}{ GA } & \multirow{2}{*}{ GG } & \multirow{2}{*}{$\mathrm{CT}$} & 5 & 5.25 & 0 & 0 \\
\hline Women $^{\dagger}$ & & & & 1 & 1.1 & 0 & 0 \\
\hline $\mathrm{Men}^{\dagger}$ & \multirow{2}{*}{ GG } & \multirow{2}{*}{ GA } & \multirow{2}{*}{$\mathrm{CT}$} & 0 & 0 & 0 & 0 \\
\hline Women $^{\dagger}$ & & & & 2 & 2.3 & 3 & 5.7 \\
\hline $\operatorname{Men}^{\dagger}$ & \multirow{2}{*}{ GG } & \multirow{2}{*}{ GG } & \multirow{2}{*}{$\mathrm{TT}$} & 11 & 11.6 & 2 & 5.5 \\
\hline Women $^{\dagger}$ & & & & 9 & 10.2 & 5 & 9.4 \\
\hline $\operatorname{Men}^{\dagger}$ & \multirow{2}{*}{ GA } & \multirow{2}{*}{ GG } & \multirow{2}{*}{ TT } & 1 & 1.05 & 0 & 0 \\
\hline Women ${ }^{\dagger}$ & & & & 0 & 0 & 0 & 0 \\
\hline $\mathrm{Men}^{\dagger}$ & \multirow{2}{*}{ GG } & \multirow{2}{*}{ GA } & \multirow{2}{*}{$\mathrm{TT}$} & 1 & 1.05 & 0 & 0 \\
\hline Women $^{\dagger}$ & & & & 1 & 1.1 & 0 & 0 \\
\hline Men & \multicolumn{3}{|c|}{$\begin{array}{l}\text { GA or/and GA } \\
\text { or/and TT }\end{array}$} & 19 & $20 *$ & 2 & 5.5 \\
\hline Women & \multicolumn{3}{|c|}{$\begin{array}{l}\text { GA or/and GA } \\
\text { or/and CT }+\mathrm{TT}\end{array}$} & 50 & $56.8 *$ & 22 & 41.5 \\
\hline
\end{tabular}

$\overline{n-\text { group size; } F 2: \mathrm{A}-20210 \mathrm{~A} ; \mathrm{G}-20210 \mathrm{G}, F 5: \mathrm{A}-1691 \mathrm{~A} ; \mathrm{G}-}$ 1691G, MTHFR: T - 677T, C $-677 \mathrm{C} ;^{\dagger}-$ genotypes, considered as unfavorable; *Significant at $\mathrm{P}<0.05$.

with at least one risk allele of the MTHFR $677 \mathrm{~T}$ was higher in women from the case group $(54.5 \%)$ than in women from the control group II (41.5\%).

So, we can assume that carrying the MTHFR 677T, that results in total homocysteine (tHcy) level increase [28-30], is a risk factor for the stroke development in women. As mentioned earlier, endothelium dysfunction is increased due to sex hormones level decline with age. Homocysteine may impair endothelium function by decreasing both the production of vasodilator sub- stances and their bio-availability to smooth muscle cells [30]. The damaged blood vessels endothelium increases thrombocyte adhesion and risk of thrombotic event. Many factors are related to circulating tHcy concentrations [29]. Fasting plasma tHcy concentration is consistently higher in men than in women, and increases with age $[22,29]$. In addition, homocysteine levels are reported to be lower in pre-menopausal women than in men and post-menopausal women. Because tHcy concentrations are strongly modulated by gender and age, interactions among these factors, folate status and the C677T mutation in the MTHFR gene locus may explain the inconsistent association of this polymorphism with the risk of occlusive vascular disease. Changes in sex hormones and tHcy levels seem to have strongly pronounced influence on endothelium dysfunction development in women. Thus, carrying the C677T mutation in MTHFR gene may additionally increase the risk of endothelium dysfunction, and as a result, the risk of stroke development in women with the $677 \mathrm{~T}$ allele is higher comparing to men.

For revealing a possible cumulative influence of the polymorphic variants G20210A, G1691A and C677T of F2, F5 and MTHFR genes, combined genotypes distribution analysis was performed (tabl. 2).

After combined genotypes distribution analysis of the polymorphic variants G20210A, G1691A and C677T of F2, F5 and MTHFR genes, total frequency of unfavorable combined genotypes, which included at least one of the risk alleles of $F 2$ and/or $F 5$ and/or bearing two copies of the MTHFR 677T, was higher in men from the case group (20\%) than in men from the control group II (5.5\%). In women from the case group $(56.8 \%)$ frequency of total unfavorable combined genotypes which included at least one of the F2, F5, $M T H F R$ genes risk alleles was higher than in women from the control group II (41.5\%).

Therefore, our findings suggest some common trend for interactions of unfavorable combined genotypes in complex disorder development. The genetic factors which are minor or insignificant, when present alone, can exert an additive effect. Certain specific pairs of mutations and clinical risk factors in combination might yield significant complex risk factors for ischemic stroke. Besides the classical clinical risk factors, rapidly increasing knowledge of unfavorable genetic 
mutations will permit recognition of a larger population at high risk of ischemic stroke, and this may lead to more effective prevention.

We should point out, that larger case and control groups for verification of the observed interactions in our study in higher significant level are required.

Our data show that the polymorphic variant 20210A of F2 gene can be a higher risk factor for the stroke development in men. On the other hand, for women a higher risk factor for the stroke development seems to be the polymorphic variant 1691A of F5 gene. We also assume that the polymorphic variant $677 \mathrm{~T}$ of MTHFR gene can be a genetic predisposition factor for the stroke development in women. Cumulative risk factor for the stroke development is revealed in a combination of unfavorable polymorphic variants 20210A, $1691 \mathrm{~A}$ and $677 \mathrm{~T}$ of the $F 2, F 5$ and MTHFR genes.

The study was supported by the NAS of Ukraine.

П. Ф. Татарський, А. М. Кучеренко, С. А. Кравченко, Д. В. Шульженко, С. М. Кузнєцова, Л. А. Лівшиць

Ішемічний інсульт серед населення України: можливе залучення поліморфних варіантів генів F2 G20210A, F5 G1691A та MTHFR C677T

Резюме

Мета. Провести аналіз зв'язку поліморфнних варіантів генів F2, F5, MTHFR ma патогенезу інсульту серед населення України. Методи. Алельні варіанти визначали серед 183 неспоріднених пацієнтів з інсультом, 100 індивідуумів із загальної популяції та 88 - здорових індивідуумів старших 65 років, методом ПЛР та ПДРФ-аналізу. Результати. «Несприятливі» поліморфні варіанти F2 20210A, F5 1691 A ma MTHFR 677T cnocmepizaлися частіше серед пацієнтів з ішемічним інсультом порівняно з контрольними групами. Висновки. Поліморфні варіанти F5 1691A ma MTHFR 677T асочійовані з випадками імемічного інсульту у жінок, варіант F2 20210A - з випадками ішемічного інсульту у чоловіків. Комбінація виявлених мутантних варіантів 1691A, 20210A і 677T генів F5, F2 і MTHFR проявляється як адитивний фактор ризику виникнення инсульту.

Ключові слова: ген фактора V Лейден (F5 G1691A), ген протромбіну (F2 G20210A), ген метилентетрагідрофолатредукmaзи (MTHFR C677T), ішемічний інсульт, комбінований генотип.

П. Ф. Татарский, А. М. Кучеренко, С. А. Кравченко, Д. В. Шульженко, С. М. Кузнецова, Л. А. Ливиии

Ишемический инсульт среди населения Украины: возможное вовлечение полиморфных вариантов генов F2 G20210A, F5 G1691A и MTHFR C677T

Резюме

Цель. Провести анализ ассоцииаци полиморфных вариантов генов F2, F5, MTHFR и патогенеза инсульта среди населения
Украины. Методы. Аллельные варианты анализировали среди 183 неродственных пациентов с инсультом, 100 индивидуумов из общей популяциии Украины и 88 здоровых индивидуумов старше 65 лет методами ПЦР и ПДРФ-анализа. Результаты. «Неблагоприятные» полиморфные варианты F2 20210A, F5 1691A и MTHFR 677T выявлялись чаще у пациентов с ишемическим инсультом по сравнению с контрольными группами. Выводы. Полиморфные варианты F5 1691A и MTHFR $677 T$ acсочиированы со случаями ишемического инсульта у женщин, вариант F2 20210A - со случаями ишемического инсульта у мужчин. Комбинации выявленных мутантных вариантов 1691A, 20210A и 677T генов F5, F2 и MTHFR проявляются как аддитивный фактор риска возникновения инсульта.

Ключевые слова: ген фактора V Лейден (F5 G1691A), ген протромбина (F2 G20210A), ген метилентетрагидрофолатредуктазы (MTHFR C677T), ишемический инсульт, комбинированный генотип.

\section{REFERENCES}

1. Madonna P., de Stefano V., Coppola A., Cirillo F., Cerbone A. M., Orefice G., Di Minno G. Hyperhomocysteinemia and other inherited prothrombotic conditions in young adults with a history of ischemic stroke // Stroke.-2002.-33, N 1.-P. 5156.

2. Meyer M. R., Haas E., Barton M. Gender differences of cardiovascular disease: new perspectives for estrogen receptor signaling // Hypertension.-2006.-47, N 6.-P. 1019-1026.

3. Markus H. Genes for stroke// J. Neurol. Neurosurg. Psychiatry.-2004.-75, N 9.-P. 1229-1231.

4. Margaglione M., D'Andrea G., Giuliani N., Brancaccio V., De Lucia D., Grandone E., De Stefano V., Tonali P. A., Di Minno $G$. Inherited prothrombotic conditions and premature ischemic stroke: sex difference in the association with factor V Leiden // Artherioscler. Thromb. Vasc. Biol.-1999.-19, N 7.-P. 1751-1756.

5. De Stefano V., Chiusolo P., Paciaroni K., Casorelli I., Rossi E., Molinari M., Servidei S., Tonali P. A., Leone G. Prothrombin G20210A mutant genotype is a risk factor for cerebrovascular ischemic disease in young patients // Blood.-1998.-91, N 10.-P. 3562-3565.

6. Lalouschek W., Schillinger M., Hsieh K., Endler G., Tentschert S., Lang W., Cheng S., Mannhalter C. Matched casecontrol study on factor $\mathrm{V}$ Leiden and the prothrombin G20210A mutation in patients with ischemic stroke/transient ischemic attack up to the age of 60 years // Stroke.-2005.-36, N 7.-P. 1405-1409.

7. Bertina R. M., Koeleman B. P., Koster T., Rosendaal F. R., Dirven R. J., de Ronde H., van der Velden P. A., Reitsma P. H. Mutation in blood coagulation factor $\mathrm{V}$ associated with resistance to activated protein C // Nature.-1994.-369, N 6475.P. 64-67.

8. Ridker P. M., Hennekens C. H., Lindpaintner K., Stampfer M. J., Eisenberg P. R., Miletich J. P. Mutation in the gene coding for coagulation factor $\mathrm{V}$ and the risk of myocardial infarction, stroke, and venous thrombosis in apparently healthy men // N. Engl. J. Med.-1995.-332, N 14.-P. 912-917.

9. Poort S. R., Rosendaal F. R., Reitsma P. H., Bertina R. A common genetic variation in the 39 -untranslated region of the 
prothrombin gene is associated with elevated plasma prothrombin levels and increase in venous thrombosis // Blood.1996.-88, N 10.-P. 3698-3703.

10. Maniatis T., Fritsch E. F., SambrookJ. Molecular cloning: a laboratory manual.-New York: Cold Spring Harbor Lab. publ., 1982.-545 p.

11. Koksal V., Baris I., Etlik O. Primer-engineered multiplex PCR-RFLP for detection of MTHFR C677T, prothrombin G20210A and factor V Leiden mutations // Exp. Mol. Pathol.-2007.-83, N 1.-P. 1-3.

12. Michael S., Qamar R., Akhtar F., Khan W. A., Ahmed A. C677T polymorphism in the methylenetetrahydrofolate reductase gene is associated with primary closed angle glaucoma // Mol. Vis.-2008.-14.-P. 661-665.

13. Moore J. H. Computational analysis of gene-gene interactions using multifactor dimensionality reduction // Expert Rev. Mol. Diagnost.-2004.-4, N 6.-P. 795-803.

14. Raymond M., Rousset F. GENEPOP (version 1.2): population genetics software for exact tests and ecumenicism // J. Hered.-1995.-86, N 3.-P. 248-249.

15. Excoffier L., Laval G., Schneider S. Arlequin ver. 3.0: An integrated software package for population genetics data analysis // Evol. Bioinform. Online.-2005.-1.-P. 47-50.

16. Henkens C., Bom V., Seinen A., van der Meer J. Sensitivity to activated protein $C$ : influence of oral contraceptives and sex // Thromb. Haemost.-1995.-73, N 3.-P. 402-404.

17. Jensen-Urstad K., Johansson J. Gender difference in age-related changes in vascular function // J. Int. Med.-2001.-250, N 1.-P. 29-36

18. Stampfer M. J., Colditz G. A., Willett W. C. Menopause and heart disease. A review // Ann. N. Y. Acad. Sci.-1990.592.-P. 193-203.

19. Koledova $V$. V., Khalil R. A. Sex hormone replacement therapy and modulation of vascular functionin cardiovascular disease // Expert Rev. Cardiovasc. Ther.-2007.-5, N 4.P. 777-789.

20. Orshal J. M., Khalil R. A. Gender, sex hormones, and vascular tone // Am. J. Physiol. Regul. Integr. Comp. Physiol.2004.-286, N 2.-P. R233-R249.

21. Otsuki M., Gao H., Dahlman-Wright K., Ohlsson C., Eguchi N., Urade Y., Gustafsson J. A. Specific regulation of lipocalin-type prostaglandin D synthase in mouse heart by estrogen receptor beta // Mol. Endocrinol.-2003.-17, N 9.-P. 18441855 .
22. Di Carlo C., Di Spiezio Sardo A., Bifulco G., Tommaselli G. A., Guerra G., Rippa E., Mandato V. D., Nappi C. Postmenopausal hypoestrogenism increases vasoconstrictor neuropeptides and decreases vasodilator neuropeptides content in arterial-wall autonomic terminations // Fertil. Steril.-2007.-88, N 1.-P. 95-99.

23. Gopel W., Ludwig M., Junge A. K., Kohlmann T., Diedrich $K$., Moller J. Selection pressure for the factor-V-Leiden mutation and embryo implantation // Lancet.-2001.-358, N 9289.-P. 1238-1239.

24. Majerus $P$. W. Human genetics. Bad blood by mutation // Nature.-1994.-369, N 6475.-P. 14-15.

25. Lindqvist P. G., Zoller B., Dahlback B. Improved hemoglobin status and reduced menstrual blood loss among female carriers of factor V Leiden an evolutionary advantage? // Thromb. Haemost.-2001.-86, N 4.-P. 1122-1123.

26. Liu P. Y., Death A. K., Handelsman D. J. Androgens and cardiovascular disease // Endocrinol. Rev.-2003.-24, N 3.P. 313-340.

27. Traish A. M., Saad F., Feeley R. J., Guay A. The dark side of testosterone deficiency: III. Cardiovascular disease // J. Androl.-2009.--30, N 5.-P. 477-494.

28. Russo G. T., Friso S., Jacques P. F., Rogers G., Cucinotta D., Wilson P. W., Ordovas J. M., Rosenberg I. H., Selhub J. Framingham Offspring Study Cohort. Age and gender affect the relation between methylenetetrahydrofolate reductase $\mathrm{C} 677 \mathrm{~T}$ genotype and fasting plasma homocysteine concentrations in the Framingham Offspring Study Cohort // J. Nutr.-2003.133, N 11.-P. 3416-3421.

29. Dierkes J., Jeckel A., Ambrosch A., Westphal S., Luley C., Boeing $H$. Factors explaining the difference of total homocysteine between men and women in the European Investigation Into Cancer and Nutrition Potsdam Study // Metabolism.2001.-50, N 6.-P. 640-645.

30. Woo K. S., Chook P., Lolin Y. I., Cheung A. S., Chan L. T., Sun Y. Y., Sanderson J. E., Metreweli C., Celermajer D. S. Hyperhomocyst(e)inemia is a risk factor for arterial endothelial dysfunction in humans // Circulation.-1997.-96, N 8.P. 2542-2544.

УДК $575.11+577.21$

Received 20.03.10 